\title{
Clinical outcomes of transfusion-associated iron overload in patients with refractory chronic anemia
}

This article was published in the following Dove Press journal:

Patient Preference and Adherence

22 April 2014

Number of times this article has been viewed

\section{Chong Gao}

Li Li

Baoan Chen

Huihui Song

Jian Cheng

Xiaoping Zhang

Yunyu Sun

Department of Hematology and Oncology, Key Department of Jiangsu Medicine, Zhongda Hospital, Medical School, Southeast University, Nanjing, Jiangsu Province, People's Republic of China
Correspondence: Baoan Chen Department of Hematology, Zhongda Hospital, Medical School, Southeast University, Nanjing 210009, Jiangsu Province, People's Republic of China Tel +86258327 2006

Fax+86258327 20II

Email cba8888@hotmail.com
Background: The purpose of this study was to evaluate the clinical outcomes of transfusionassociated iron overload in patients with chronic refractory anemia.

Methods: Clinical manifestations, main organ function, results of computed tomography (CT), endocrine evaluation, and serum ferritin levels were analyzed retrospectively in 13 patients who were transfusion-dependent for more than 1 year (receiving $>50$ units of red blood cells) to determine the degree of iron overload and efficacy of iron-chelating therapy.

Results: Serum ferritin levels increased to $1,830-5,740 \mathrm{ng} / \mathrm{mL}$ in all patients. Ten patients had abnormal liver function. The CT Hounsfield units in the liver increased significantly in eleven patients, and were proportional to their serum ferritin levels. Skin pigmentation, liver dysfunction, and endocrine dysfunction were observed in nine patients with serum ferritin $>3,500 \mathrm{ng} / \mathrm{mL}$, eight of whom have since died. Interestingly, serum ferritin levels did not decrease significantly in nine transfusion-dependent patients who had received 15-60 days of iron-chelating therapy.

Conclusion: Transfusion-dependent patients may progress to secondary iron overload with organ impairment, which may be fatal in those who are heavily iron-overloaded. The CT Hounsfield unit is a sensitive indicator of iron overload in the liver. Iron chelation therapy should be initiated when serum ferritin is $>1,000 \mathrm{ng} / \mathrm{mL}$ and continued until it is $<1,000 \mathrm{ng} / \mathrm{mL}$ in transfusional iron-overloaded patients.

Keywords: anemia, aplastic, iron overload, myelodysplastic syndromes

\section{Introduction}

Regular red blood cell transfusion is a rapid and effective treatment for refractory chronic anemia, including thalassemia, sickle cell anemia, myelodysplastic syndrome, and aplastic anemia. As a consequence, transfusional iron overload is a very common complication in these patients. A $1 \mathrm{~mL}$ suspension of red blood cells contains $1.16 \mathrm{mg}$ of iron, so one unit of red blood cells contains $200-250 \mathrm{mg}$ of iron. The body has limited mechanisms for excreting excess iron, so most people would develop iron overload after transfusion with 10-20 units of red blood cells. Children with thalassemia often develop transfusion-related iron overload after chronic transfusion. Iron is deposited in parenchymal tissues and in reticuloendothelial cells, and its accumulation causes progressive damage to the liver, heart, and endocrine system if a chelating therapy is not introduced. Patients may present with hepatomegaly, liver dysfunction, heart failure, skin pigmentation, hypogonadism, diabetes mellitus, and/or arthropathy. Iron-chelating therapy is an important part of the treatment for thalassemia, decreasing the incidence of transfusion-related iron overload and the associated mortality, 
and prolonging patient survival. ${ }^{1}$ At present, most doctors still do not pay enough attention to the hazards arising from repeated transfusions. This retrospective study investigated the clinical outcomes in 13 patients with transfusion-related iron overload.

\section{Patients and methods \\ Patients}

Thirteen patients with acquired chronic refractory or inherited anemia reliant on blood transfusions (over two units per month) for more than 1 year were evaluated retrospectively at our hospital. The median age of the patients was 52 (range 25-82) years. Five patients had chronic aplastic anemia, three had severe aplastic anemia, one had myeloproliferative disease, one had thalassemia and had had a splenectomy aged 1.5 years, and three had myelodysplastic syndrome (refractory anemia, 5q-syndrome, and refractory anemia with ringed sideroblasts). No patient had diabetes mellitus or a history of treatment with glucocorticoids. The hematologic characteristics of the patients are shown in Table 1. Two patients (cases 9 and 11) were taking cyclosporin A and three were taking diuretics.

Before iron chelating therapy, we assessed and recorded their blood sugar, hepatitis B virus markers, liver and renal function, thyroxine, serum ferritin (before iron-chelating therapy, with infection excluded), electrocardiogram, color Doppler echocardiogram, and computed tomography (CT) scan results. No liver biopsies were performed due to the risk of the procedure such as that of thrombocytopenia.

\section{Iron-chelating therapy}

Defetoxamine was given according to the patients' serum ferritin levels. When serum ferritin was $<2,000 \mathrm{ng} / \mathrm{mL}$, the patient was given defetoxamine $25 \mathrm{mg} / \mathrm{kg} /$ day and when it was $>2000 \mathrm{ng} / \mathrm{mL}$, the patient was given $35 \mathrm{mg} / \mathrm{kg} /$ day.

\section{Statistical analysis}

We used the Wilcoxon signed-rank test to identify any differences between transfusional iron-overloaded patients and normal individuals. $P<0.05$ was considered to be statistically significant. All statistical analyses were performed using Statistical Package for the Social Sciences version 13.0 software (SPSS Inc., Chicago, IL, USA).

\section{Results}

\section{Clinical symptoms}

Six patients (cases 3, 4, 6, 8, 12, and 13) had anorexia and marasmus (weight loss $>5 \mathrm{~kg}$ over 6 months), and one patient (case 4) had diarrhea at the same time. Facial skin pigmentation was found in ten patients, and two of them (cases 2 and 3) had obvious black specks of skin pigmentation around their ankles.

\section{Serum ferritin}

All 13 patients in our study group had high serum ferritin levels, ranging from $1,830 \mathrm{ng} / \mathrm{mL}$ to $5,740 \mathrm{ng} / \mathrm{mL}$. Nine patients had levels $>3,500 \mathrm{ng} / \mathrm{mL}$ and four had levels $<3,500 \mathrm{ng} / \mathrm{mL}$ (Table 1).

\section{CT scan}

An enlarged liver was detected in three of the 13 patients and splenomegaly in five patients. CT Hounsfield units in the spleen were normal in these patients, but were markedly increased in the liver in ten patients $(76.9 \%)$.

Table I Hematologic characteristics of I 3 patients with transfusion-associated iron overload

\begin{tabular}{|c|c|c|c|c|c|}
\hline Patient & Sex & $\begin{array}{l}\text { Age } \\
\text { (years) }\end{array}$ & Diagnosis & $\begin{array}{l}\text { Transfusion } \\
\text { units }\end{array}$ & SF (ng/mL) \\
\hline I & $\mathrm{F}$ & 55 & Refractory anemia & 280 & 3,564 \\
\hline 2 & $M$ & 25 & Chronic aplastic anemia & 252 & 4,586 \\
\hline 3 & $M$ & 60 & Chronic aplastic anemia & 236 & 4,339 \\
\hline 4 & $M$ & 73 & Myeloproliferative disease & 320 & 4,085 \\
\hline 5 & $M$ & 26 & Severe aplastic anemia & 180 & 3,596 \\
\hline 6 & $\mathrm{~F}$ & 56 & Chronic aplastic anemia & 246 & 3,687 \\
\hline 7 & $\mathrm{~F}$ & 47 & Chronic aplastic anemia & 144 & 3,586 \\
\hline 8 & $\mathrm{~F}$ & 52 & 5q-syndrome & 288 & 4,258 \\
\hline 9 & $\mathrm{~F}$ & 25 & Severe aplastic anemia & 384 & $\mathrm{I}, 857$ \\
\hline 10 & $M$ & 68 & Chronic aplastic anemia & 54 & 1,830 \\
\hline 11 & $M$ & 32 & Severe aplastic anemia & 92 & 1,985 \\
\hline 12 & $M$ & 82 & $\begin{array}{l}\text { Refractory anemia with ringed } \\
\text { sideroblasts }\end{array}$ & 78 & 2,550 \\
\hline 13 & $M$ & 43 & Thalassemia & 40 & 5,740 \\
\hline
\end{tabular}

Abbreviations: SF, serum ferritin; M, male; F, female. 
Table 2 Hepatic evaluation in 13 patients with transfusionassociated iron overload

\begin{tabular}{ll}
\hline Variable & $\begin{array}{l}\text { Patients with abnormal } \\
\text { results (n) }\end{array}$ \\
\hline Alanine aminotransferase & 10 \\
Glutamic oxaloacetic transaminase & 8 \\
Alkaline phosphatase & 5 \\
Gamma-glutamyl transferase & 5 \\
Bilirubin & 4 \\
Albumin & 6 \\
\hline
\end{tabular}

Importantly, we identified that CT Hounsfield units for the liver were proportional to serum ferritin levels (Figure 1).

\section{Hepatic evaluation}

Ten patients had liver dysfunction, and the most frequent abnormalities were higher serum levels of alanine aminotransferase, glutamic oxaloacetic transaminase, alkaline phosphatase, gamma-glutamyl transferase, and bilirubin, and a decreased albumin level (Table 2). One patient was positive for hepatitis $\mathrm{C}$ antibody, and the other 12 patients were negative for hepatitis $\mathrm{B}$ virus, hepatitis $\mathrm{C}$ virus, and human immunodeficiency virus.

\section{Cardiac evaluation}

Four of the 13 patients were diagnosed as having heart failure on physical examination and serum brain natriuretic peptide levels. Left bundle branch block was noted on routine 12-lead electrocardiography in three patients. One patient had paroxysmal supraventricular tachycardia, but no other arrhythmias or conduction disturbances were found. Echocardiography revealed atrial enlargement or ventricular hypertrophy (and both in eight patients), and left ventricular ejection fraction was decreased to a varying extent in four cases.

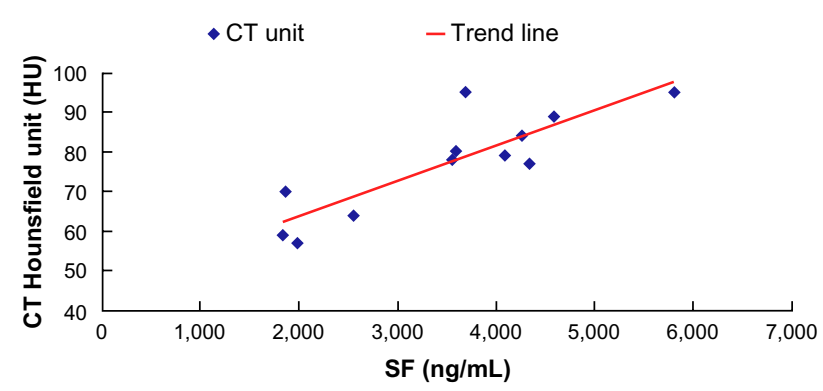

Figure I Correlation between Hounsfield units $(\mathrm{HU})$ and serum ferritin levels in patients with transfusion-associated iron overload.

Abbreviations: $\mathrm{CT}$, computed tomography; SF, serum ferritin.

\section{Endocrine evaluation}

Free T3 and free T4 were decreased in four patients with a diagnosis of iron overload, and thyrotropin-stimulating hormone was higher than normal. In three patients, fasting blood sugar was normal at diagnosis of the primary disease, but increased to an abnormal level after long-term transfusions. Two of these patients were diabetic and the third had impaired glucose tolerance. Of the eight male patients, five had testosterone levels lower than normal for their age, ranging from $0.09 \mathrm{ng} / \mathrm{mL}$ to $2.45 \mathrm{ng} / \mathrm{mL}$ (normal range $3-5.7 \mathrm{ng} / \mathrm{mL}$ ). Of the five female patients, one (case 9) was of childbearing age, and had a decreased estrogen level of $19 \mathrm{pg} / \mathrm{mL}$.

\section{Treatment \\ Quantity of red blood cell transfusion}

All patients were blood transfusion-dependent for 18-60 months, and the median quantity of red cells given was $236(56-384)$ units.

\section{Effects of iron-chelating therapy}

Nine patients received iron-chelating therapy over a period of 15-60 days. For those patients reliant on blood transfusions and having a serum ferritin level $>3,000 \mathrm{ng} / \mathrm{mL}$, serum ferritin did not decrease significantly after iron-chelating therapy, and their symptoms and signs of iron overload did not resolve. Three patients (case 9, 10, and 11) became free from blood transfusions after effective treatment. The serum ferritin level in one of these three patients (case 9) decreased to $1,160 \mathrm{ng} / \mathrm{mL}$, decreased in another (case 11) to $1,680 \mathrm{ng} / \mathrm{mL}$ after iron-chelating therapy for 30 days, and decreased to $1,320 \mathrm{ng} / \mathrm{mL}$ in the remaining patient (case 10) without any iron-chelating therapy.

\section{Follow-up}

Since this study was performed, eight of the patients have died; all had a serum ferritin level $>3,500 \mathrm{ng} / \mathrm{mL}$ and had been blood transfusion-dependent for 3-5 years. One patient (case 1) died of complications after allotransplantation, and the others died of heart, liver dysfunction, or severe infection. Two patients who are still alive are receiving iron-chelating therapy intermittently (cases 5 and 12) and the other three patients (cases 9, 10, and 11) have achieved partial or complete hematological remission.

\section{Discussion}

Patients who require regular blood transfusions develop iron overload that damages the liver, the endocrine system, and 
most importantly the heart. Iron overload also impairs the proliferation of erythroid progenitor cells, which may worsen already poor hematopoietic function. ${ }^{2}$ The 13 patients in our study were diagnosed as having iron overload on the basis of a history of long-term blood transfusions, increased serum ferritin, skin pigmentation, hepatosplenomegaly, liver dysfunction, increased Hounsfield units in the liver, arrhythmia and heart failure, and/or cryptorrhea.

We usually make a diagnosis of iron overload on the results of liver or myocardial biopsy, use of a superconducting quantum interference device, serum ferritin, transferrin saturation, urinary iron measured 24 hours after iron-chelating therapy, magnetic resonance imaging, and/or major organ function. Serum ferritin is easy to evaluate, but is also easily affected by a number of conditions, including infection, malignancy, and vitamin $\mathrm{C}$ deficiency, which leads to low specificity. Liver or myocardial biopsy is the most sensitive way to detect iron content, but its invasiveness and the risk of thrombocytopenia limit its use for this purpose. The superconducting quantum interference device is expensive, and few hospitals can afford one. Therefore, it is necessary to discover new ways to evaluate iron content. We found that Hounsfield units in the liver are a sensitive indicator for evaluating iron overload. In our study, $76.9 \%$ of patients showed increased liver density, which was reflected as an increase in Hounsfield units. Further, Hounsfield units of the liver were proportional to serum ferritin levels, and were slightly raised in the heart and spleen compared with normal. Hepatocytes are the main cells containing iron in patients with iron overload and can reflect their iron state, which may explain the increase in Hounsfield units seen in patients with iron overload. ${ }^{3}$

Serum ferritin levels and the quantity of red blood cells received are two factors that negatively affect the prognosis of low-risk myelodysplastic syndrome. Takatoku et al investigated 292 patients with transfusion-related iron overload, and found that most of them $(65 \%)$ with serum ferritin $>5,000$ $\mathrm{ng} / \mathrm{mL}$ died of heart failure or liver failure, with mortality rates of $24 \%$ and $6.7 \%$, respectively. ${ }^{4}$ Malcovati reported that patients with refractory anemia, refractory anemia with ringed sideroblasts, or 5q-syndrome who had serum ferritin $>2,500 \mathrm{ng} / \mathrm{mL}$ or had received blood transfusions of $3-4$ units per month had a 5 -year overall survival rate of only $15 \%$ and $10 \%$, respectively. ${ }^{5}$ Our results were similar to those of the above studies. In our series, all patients who died had serum ferritin $>3,500 \mathrm{ng} / \mathrm{mL}$, and often had dysfunction of more than two organs. They had generally been blood transfusiondependent for 3-5 years. The patients who are now blood transfusion-free had no obvious cutaneous pigmentation or organ dysfunction, and serum ferritin declined gradually in all cases. Therefore, the most effective way to protect patients from iron overload is to control primary diseases and free patients of the need for blood transfusion.

Deferoxamine, deferiprone, and deferasirox are the three major iron-chelating agents used in patients with iron overload. ${ }^{6}$ However, it takes months, even years, to reduce serum ferritin to a safe range. ${ }^{7}$ Of the nine patients received iron-chelating therapy in our study, seven had serum ferritin $>3,500 \mathrm{ng} / \mathrm{mL}$ at the beginning of this treatment. Iron-chelating therapy in this group was intermittent and the cumulative courses were for only 15-60 days, with little improvement in serum ferritin or organ function. Patients who have received red blood cell transfusions ( $>40 \mathrm{U}$ in adults or $>100 \mathrm{~mL} / \mathrm{kg}$ in children), and have serum ferritin levels persistently $>1,000 \mathrm{ng} / \mathrm{mL}$ should undergo iron-chelating therapy as soon as possible to decrease their serum ferritin to a safe range of 500-1,000 ng/ $\mathrm{mL}$, so they can avoid the side effects of iron overload. It is possible for patients with severe aplastic anemia to achieve hematopoietic recovery after iron-chelating therapy. ${ }^{8}$

In summary, Hounsfield units in the liver were an indicator of body iron in this case series. Timely and regular ironchelating therapy can improve function of the heart, liver, and endocrine system in patients with transfusion-associated iron overload, and may improve hematopoietic function.

\section{Disclosure}

The authors report no conflicts of interest in this work.

\section{References}

1. Olivieri NF, Brittenham GM. Iron-chelating therapy and the treatment of thalassemia. Blood. 1997;89:739-761.

2. Hartmann J, Braulke F, Sinzig U, et al. Iron overload impairs proliferation of erythroid progenitors cells (BFU-E) from patients with myelodysplastic syndromes. Leuk Res. 2013;37:327-332.

3. Mitnick JS, Bosniak MA, Megibow AJ, et al. CT in B-thalathassemia: iron deposition in the liver, spleen and lymph nodes. AJR Am J Roentgenol. 1981;136:1191-1194.

4. Takatoku M, Uchiyama T, Okamoto S, et al. Retrospective nationwide survey of Japanese patients with transfusion-dependent MDS and aplastic anemia highlights the negative impact of iron overload on morbidity/ mortality. Eur J Hematol. 2007;78:487-494.

5. Malcovati L. Impact of transfusion dependency and secondary iron overload on the survival of patients with myelodysplastic syndromes. Leuk Res. 2007;31 Suppl 3:S2-S6.

6. Hoffbrand AV, Taher A, Cappellini MD. How I treat transfusional iron overload. Blood. 2012;120:3657-3669

7. Wells RA, Leber B, Buckstein R, et al. Iron overload in myelodysplastic syndromes: a Canadian consensus guideline. Leuk Res. 2008;32: 1338-1353.

8. Parch SJ, Han CW. Complete hematopoietic recovery after continuous iron chelation therapy in a patient with severe aplastic anemia with secondary hemochromatosis. J Korean Med Sci. 2008;23: 320-323. 
Patient Preference and Adherence

Dovepress

\section{Publish your work in this journal}

Patient Preference and Adherence is an international, peer-reviewed, open access journal focusing on the growing importance of patient preference and adherence throughout the therapeutic continuum. Patient satisfaction, acceptability, quality of life, compliance, persistence and their role in developing new therapeutic modalities and compounds to optimize clinical outcomes for existing disease states are major areas of interest. This journal has been accepted for indexing on PubMed Central. The manuscript management system is completely online and includes a very quick and fair peer-review system. Visit http://www.dovepress.com/ testimonials.php to read real quotes from published authors.

Submit your manuscript here: http://www.dovepress.com/patient-preference-and-adherence-journal 